\title{
Synthesis of an aspidosperma alkaloid precursor: synthesis of $(+)$-aspidospermidine
}

\author{
Dino Gnecco, ${ }^{\text {* }}$ Edna Vázquez, ${ }^{\mathrm{a}}$ Alberto Galindo, ${ }^{\mathrm{a}}$ Joel L. Terán, ${ }^{\mathrm{a}}$ Laura Orea, \\ Sylvain Bernès, ${ }^{a}$ and R.G. Enríquez ${ }^{b}$ \\ ${ }^{a}$ Centro de Química del Instituto de Ciencias. BUAP. 14 Sur 6301. C.P. 72570 \\ Ciudad Universitaria Puebla, Pue. México \\ ${ }^{b}$ Instituto de Química, UNAM, Cd. Universitaria, Mexico, D. F. 04510 \\ E-mail:dgnecco@siu.buap.mx
}

\begin{abstract}
Dedicated to Instituto de Química. Universidad Nacional Autónoma de México in recognition of its valuable contribution to chemistry in Mexico
\end{abstract}

(received 21 Aug 03; accepted 22 Dec 03; published on the web 31 Dec 03)

\begin{abstract}
The aspidosperma alkaloid precursor (-)-(4aR,8aS,8R)-4a-ethyl-decahydroquinolin-7-one 7 (hydrolilolidone) was prepared from (+)-(1'S,4aR,8aS)-4a-ethyl-1-(1'-phenylethyl)octahydroquinolin-7-one 3 . In addition, a synthesis of (+)-aspidospermidine 9 using compound 7 as starting material is described.
\end{abstract}

Keywords: Alkaloids, hydrolulolidone, (+)-aspidospermidine

\section{Introduction}

The Aspidosperma family represents one of the largest groups of indole alkaloids with more than 250 compounds isolated from various biological sources and among these is naturally occurring aspidospermidine. The basic skeletal features of these compounds, particularly the complex pentacyclic ABCDE framework, can be seen in the namesake of the family aspidospermidine. The pioneering work of Stork in 1963, who succeeded in achieving the first total synthesis of racemic aspidospermine, was focused upon the use of the racemic 4a-ethyl-octahydroquinolin-7one, precursor of the pivotal CDE-type tricyclic keto-amine intermediate (hydrolilolidone), which was converted into aspidospermine through a Fischer indole synthesis ${ }^{1,2,3}$ (Scheme 1). 


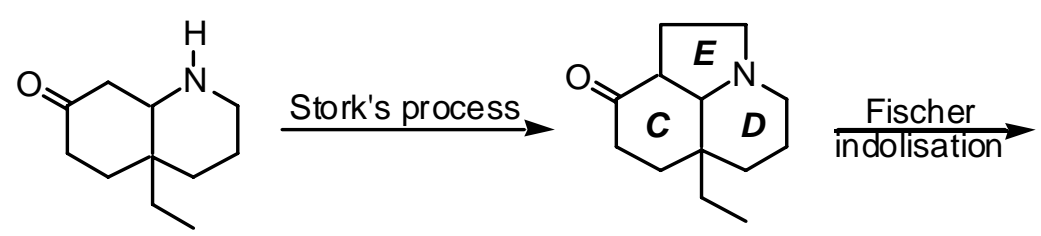

( \pm )-4a-Ethyl-octahydroquinolin-7-one

(士)-Tricyclic keto-amine

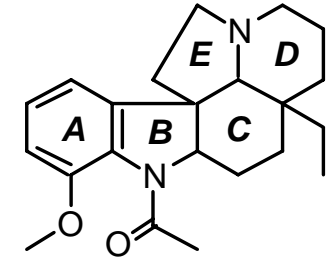

$( \pm)$-Aspidospermine

\section{Scheme 1}

\section{Results and Discussion}

In a previous publication, ${ }^{4}$ we reported the synthesis of (-)-(1'S,4aS,8aR)-4a-ethyl-1-(1'phenylethyl)-octahydroquinolin-7-one 2 and the (+)-(1'S,4aR,8aS)-4a-ethyl-1-(1'-phenylethyl)octahydroquinolin-7-one 3 with a diastereomeric enhancement of $33 \%$ which was particularly high compared to that from a similar study reported by Jankowski et al. ${ }^{5}$ In addition, we have also demonstrated by X-ray analysis that the absolute configuration for $\mathrm{C}(4 \mathrm{a})$ and $\mathrm{C}(8 \mathrm{a})$ of $\mathbf{3}$ were $(R)$ and $(S)$ respectively (Scheme 2).
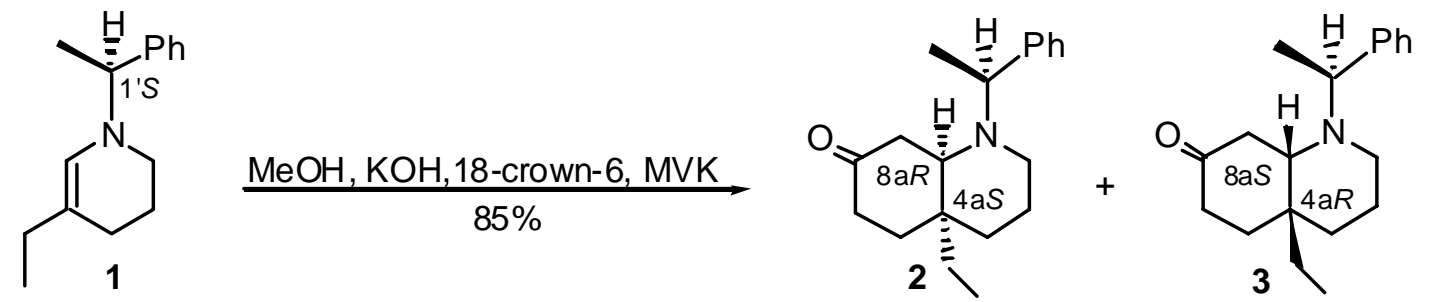

\section{Scheme 2}

Compound $(+)-(1 ' S, 4 \mathrm{a} R, 8 \mathrm{a} S)-3$ is stereochemically interesting and synthetically important after removal the 2-phenylethyl auxiliary. In this context, we investigated the catalytic hydrogenation conditions to remove this auxiliary. When the catalytic hydrogenation is carried out at $\mathrm{pH}$ ca. 1-4, compound 4 is obtained in 15\% yield. However, if this process is carried out at $\mathrm{pH}$ ca. 5-6, this compound is obtained in $90 \%$ yield. (Scheme 3).
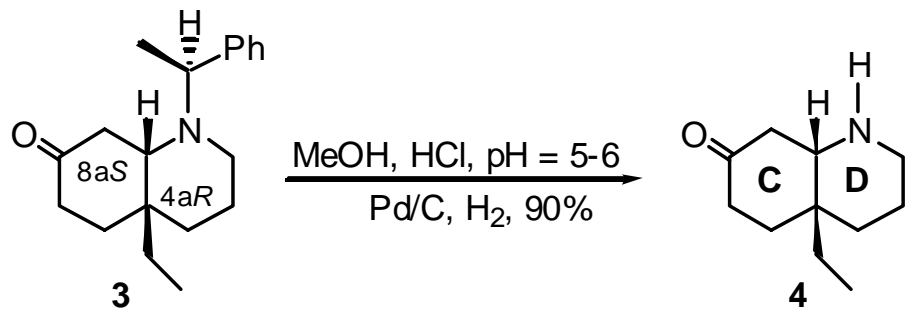

\section{Scheme 3}


In order to determine the absolute configuration of the stereogenic centers $\mathrm{C}(4 \mathrm{a})$ and $\mathrm{C}(8 \mathrm{a})$ and the $\mathrm{CD}$ ring junction stereochemistry of $\mathbf{4}$, this compound was converted into the corresponding hydrobromide $\mathbf{4 H B r}$, crystallized and analyzed by X-ray diffraction. The absolute configuration of the stereogenic centers $\mathrm{C}(4 \mathrm{a})$ and $\mathrm{C}(8 \mathrm{a})$ were unambiguously determined as $(R)$ and $(S)$ respectively. The X-ray absolute configurations are thus in agreement with that observed in $\mathbf{3}$ and support the fact that the cis CD ring junction was controlled after hydrogenolisis of $\mathbf{3}$. (Figure 1).

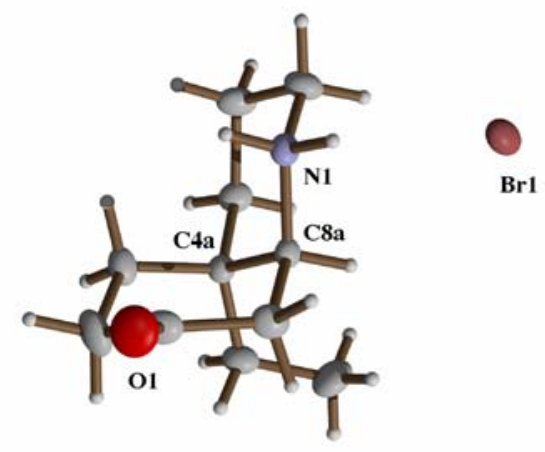

Figure 1

Considering the adequate stereochemistry of $4(4 \mathrm{a} R, 8 \mathrm{a} S)$, this compound was used to prepare 6. For this purpose, compound 4 was treated with chloroacetyl chloride in presence of triethylamine giving the chloroacetamide $\mathbf{5}$. Further, treatment of $\mathbf{5}$ with potassium tert-butoxide at room temperature afforded the enantiopure tricyclic keto-lactam $\mathbf{6}$ in quantitative yield. The cis alignment $\mathrm{CH}_{3}-\mathrm{CH}_{2} / \mathrm{C}-\mathbf{H 8}$ and C-H8/C-H8a of 6 was established by ${ }^{1} \mathrm{H}$ NMR ROESY experiments. (Scheme 4).

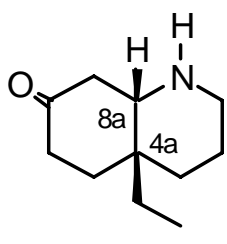

4

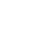

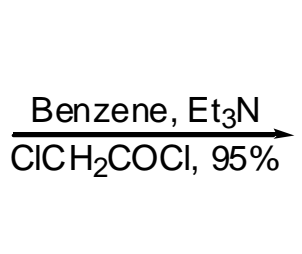

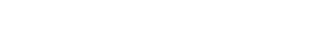

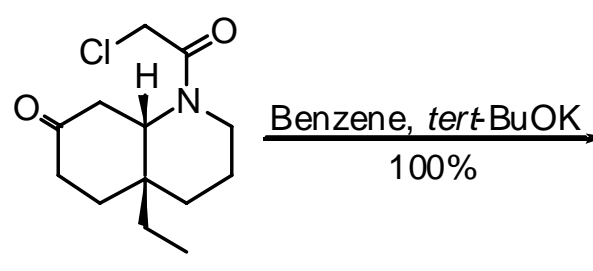

5

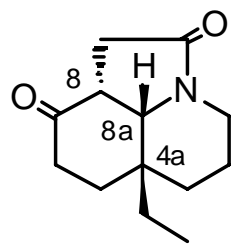

$(4 a R, 8 a S, 8 R)-6$

\section{Scheme 4}

The diastereospecific cyclization observed in this process can be explained by the presence of a rigid transition state (Enol-5), where the chloro-acetyl group is located exclusively over the favorable diastereotopic face and the anion at C-8 generated in equilibrium with the Enol-5, can displace the chlorine atom through an $\mathrm{S}_{\mathrm{N}} 2$ mechanism to give the enantiopure compound 6 . (Figure 2). 

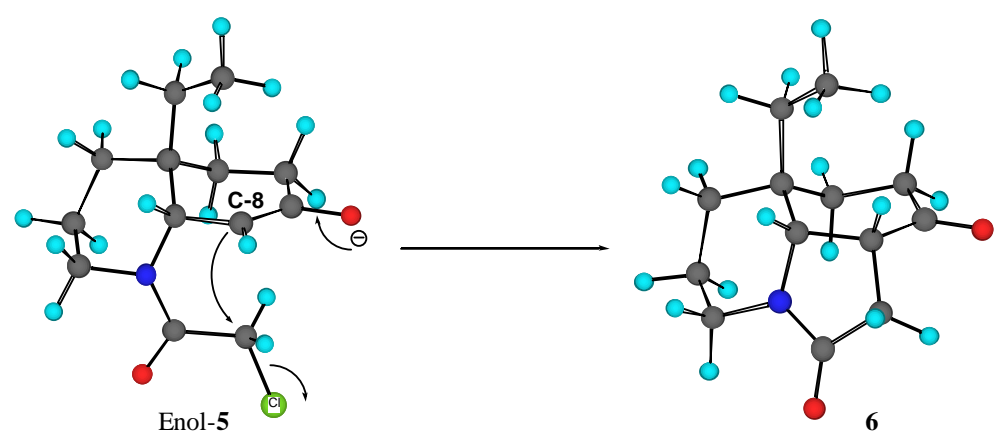

Figure 2

Furthermore, ketalization of $\mathbf{6}$ with ethylenglycol in presence of $p$-toluensulfonic acid, reduction with lithium aluminium hydride, and regeneration of the ketonic function, afforded 7. Assignments in ${ }^{1} \mathrm{H}$ NMR for 7 were confirmed by ${ }^{1} \mathrm{H}$ and ${ }^{13} \mathrm{C}$ NMR correlation techniques. (Scheme 5).
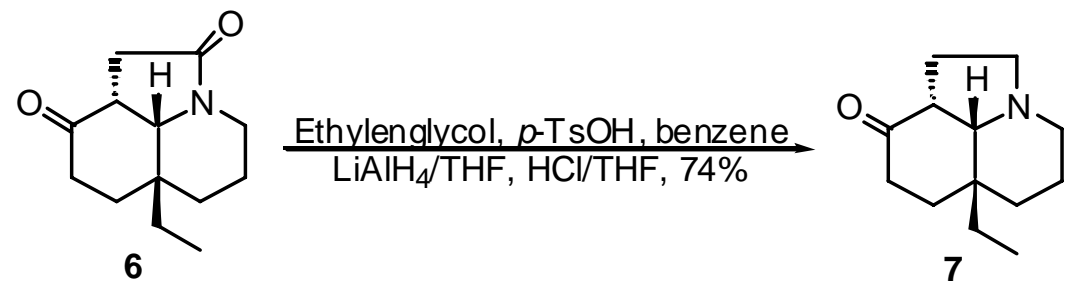

\section{Scheme 5}

Synthesis of (+)-Aspidospermidine 9. Having established the stereochemistry ${ }^{2}$ and the CDE ring junction of $\mathbf{7}^{2}$, this compound was treated with phenyhydrazine ${ }^{1}$ to produce the $1,2-$ dehydroaspidospermidine $\mathbf{8}$. Later, reduction of $\mathbf{8}$ with sodium borohydride in methanol gave the aspidospermidine $\mathbf{9}$. All data of compound $\mathbf{9}$, were found to be comparable to those reported. ${ }^{6,7,8}$ (Scheme 6).<smiles>CC[C@]12CCCN3CC[C@H](C(=O)CC1)[C@]32C</smiles>

7
Acetic acid, phenylhydrazine $65 \%$

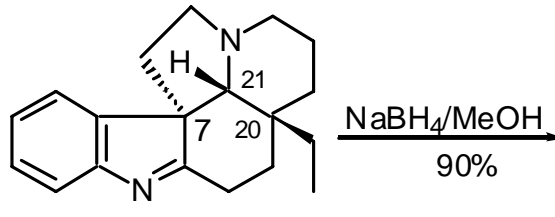

(7S,20R ,21R)-8

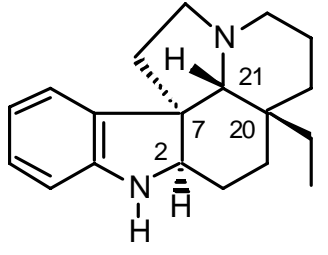

(2R,7R,20R,21R)-9

\section{Scheme 6}

\section{Conclusions}


We have described a simple and clean procedure in four steps to prepare the enantiopure alkaloid precursor 7 (hydrolilolidone) in $63.3 \%$ overall yield using chiral, nonracemic bicyclic lactam 3 as starting material. Finally, the synthesis of (+)-aspidospermidine $\mathbf{9}$ was completed using $\mathbf{3}$ as starting material in six steps with $37.0 \%$ overall yield.

\section{Experimental Section}

General Procedures. ${ }^{1} \mathrm{H}$ NMR spectra of $\mathrm{CDCl}_{3}$ solutions were recorded with a Varian Unity instrument at $400 \mathrm{MHz}$ (internal tetramethylsilane as reference). IR spectra were obtained with a Nicolet FT-IR Magna 750 spectrometer. Chromatography was carried out using $\mathrm{Al}_{2} \mathrm{O}_{3}$. Optical rotations were determined at room temperature with a Perkin-Elmer 341 polarimeter, using a $1 \mathrm{dm}$ cell with a total volume of $1 \mathrm{~mL}$ and are referenced to the D-line of sodium. Mass spectra were recorded with a JEOL JEM-AX505HA instrument at a voltage of $70 \mathrm{eV}$. Melting points were determined using a Fisher-Johns apparatus and are uncorrected.

(-)-(4aR,8aS)-4a-Ethyl-octahydroquinolin-7-one (4). To a solution of 3 (0.400 g, $1.4 \mathrm{mmol})$ in $\mathrm{MeOH} / \mathrm{HCl}$ at $\mathrm{pH}=5-6, \mathrm{Pd} / \mathrm{C}(10 \%, 0.040 \mathrm{~g})$ was added. The mixture was stirred at room temperature for $1 \mathrm{~h}$ under hydrogen atmosphere. After, the mixture reaction was filtered through a bed of Celite eluting with a $\mathrm{MeOH} / \mathrm{CH}_{2} \mathrm{Cl}_{2}$ mixture. The solvent was evaporated in vacuo obtaining 4 in 90\% yield after purification by column chromatography on $\mathrm{Al}_{2} \mathrm{O}_{3}$ (petroleum ether/dichloromethane). Pale yellow oil. $[\alpha]_{\mathrm{D}}-29.0^{\circ}$ (c 1.0, EtOH); IR (KBr, $\left.\mathrm{cm}^{-1}\right)$ : 3325, 2936, 1714; ${ }^{1} \mathrm{H}$ NMR (400MHz, $\mathrm{CDCl}_{3}$ ): $\delta$ (ppm, JHz): 0.93 (t, 3H-10, 7.70); 1.28 (td, H-5, 4.77, 4.40, 13.38); 1.39-146 (m, H-3, H-4, H-9, 5.87, 7.33, 14.30); 1.59 (dt, H-5, 13.56); 1.70 (dt, H-4, 4.40, 12.83); 1.72-1.82 (sext, H-9, 7.70); 2.04 (dt, H-8, 15.03); 2.27 (m, 2H-6); 2.41 (qd, H-3, 4.77, 5.13, 5.87, 12.65); 2.58 (td, H-2, 2.93, 11.73); 2.77 (dd, H-8, 4.03, 15.03); 2.86 (broad signal, H8a); 3.04 (dt, H-2, 1.84, 11.73). ${ }^{13} \mathrm{C}$ NMR ( $\mathrm{CDCl}_{3}$ ): 7.25 (C-10); 21.74 (C-4); 26.88 (C-3); 29.08 (C-9); 32.73 (C-5); 34.93 (C-4a); 37.20 (C-6); 44.61 (C-8); 47.18 (C-2); 62.53 (C-8a); 212.21 (C-7).

X-ray ${ }^{9}$ of $4 \mathrm{HBr}$. Crystallized from methanol-acetone. Mp. $158-162^{\circ} \mathrm{C}$. Pale pink plate, crystal size: $0.50 \times 0.40 \times 0.14 \mathrm{~mm}^{3}, \mathrm{C}_{11} \mathrm{H}_{20} \mathrm{BrNO}$, orthorhombic, $P 2_{1} 2_{1} 2_{1}, a=7.5773(6), b=8.1063(6)$, $c=18.9978(16) \AA$, volume: 1166.92(16) $\AA^{3}$, Z: 4, formula weight: 262.19, density (calc.): 1.492 g.cm ${ }^{-3}$, absorption coefficient: $3.493 \mathrm{~mm}^{-1}, F(000)$ : 544. Diffractometer used: Bruker P4, Mo- $K_{\alpha}$ ( $\lambda=0.71073 \AA$ ), $2 \theta$ range: $4.28-57.98^{\circ}$ : Reflections collected: 2377 , independent reflections: $2194\left(R_{\text {int }}=5.44 \%\right)$, completeness: $99.1 \%$ to $2 \theta=57.98^{\circ}$. Absorption correction $25 \psi$-scans, transmission factors: $\min =0.420, \max =0.796 . R_{1}=4.64 \%$ for $1708 F_{0}>4 \sigma\left(F_{0}\right)$ and $w R_{2}=$ $11.91 \%$ for all data. Absolute configuration from Flack parameter: $x=-0.045(19)$. The crystallographic data have been deposited with the CCDC, UK (deposition number 196444).

(+)-(4aR,8aS)-1-(Chloroacetyl)-4a-ethyl-octahydroquinolin-7-one (5). To a solution of 4 $(0.200 \mathrm{~g}, 1.1 \mathrm{mmol})$ in dry benzene $(2 \mathrm{~mL})$ was added $\mathrm{Et}_{3} \mathrm{~N}(0.18 \mathrm{~mL})$. The mixture reaction was 
treated with a solution of chloroacetyl chloride $(0.099 \mathrm{~mL}, 0.140 \mathrm{~g}, 1.24 \mathrm{mmol})$ in benzene $(2 \mathrm{~mL}$ of) and stirred during $1 \mathrm{~h}$. Then, the reaction was treated with a solution of $\mathrm{HCl}(1 \mathrm{~N}, 3 \mathrm{~mL})$, and extracted with diethyl ether $(4 \times 50 \mathrm{~mL})$. The extract was dried over sodium sulfate and evaporated in vacuo furnishing 5 in 100 yield as pale yellow solid. $[\alpha]_{\mathrm{D}}+21.6^{\circ}\left(\right.$ c 1.0, $\left.\mathrm{CH}_{2} \mathrm{Cl}_{2}\right)$; Mp. 84-86 ${ }^{\circ} \mathrm{C}$ (lit. ${ }^{1} \mathrm{Mp} .75-77^{\circ} \mathrm{C}$ ); (lit. $\left.{ }^{2} \mathrm{Mp} .112-114^{\circ} \mathrm{C}\right)$; IR (KBr, $\mathrm{cm}^{-1}$ ): 3470, 2949, 1718, and 1640. ${ }^{1} \mathrm{H}$ NMR (400MHz, $\left.\mathrm{CDCl}_{3}\right): \delta$ (ppm, JHz): 0.83 (t, 3H-10, 7.32, 7.72); 1.20-1.96 (m, 2H3, H-4, H-5, 2H-6, 2H-9); 2.30 (dd, H-5, 6.60, 14.32); 2.44 (td, H-4, 6.24); 2.75 (t, H-8, 13.20, 14.30); 3.23 (td, H-2, 2.92, 12.48); 3.75 (d, H-8a, 12.84); 4.09 (td, H-2); 4.11 (s, 2H-12); 4.68 (dd, H-8, 5.16). ${ }^{13} \mathrm{C}$ NMR $\left(\mathrm{CDCl}_{3}\right): 7.39$ (C-10); 20.77 (C-4); 24.13 (C-3); 28.89 (C-9); 32.99 (C-5); 35.12 (C-4a); 36.67 (C-6); 39.85 (C-8); 40.75 (C-2); 41.36 (C-12); 60.95 (C-8a); 166.42 (C-11); 209.38(C-7). HRMS (FAB+): Calcd for $\mathrm{C}_{13} \mathrm{H}_{20} \mathrm{ClNO}_{2}$ : 257.1183; found: 257.1170.

(-)-(4aR,8aS,8R)-4a-Ethyl-7,10-dioxo-4a,8a,5,6,7,8-hexahydrolilolidone (6). To a solution of $5(0.283,1.09 \mathrm{mmol})$ in dry benzene $(20 \mathrm{~mL})$ was added t-BuOK $(0.392 \mathrm{~g}, 3.5 \mathrm{mmol})$. The reaction mixture was vigorously stirred for $15 \mathrm{~h}$ and then poured into $\mathrm{HCl}(1 \mathrm{~N}, 2 \mathrm{~mL})$, extracted with diethyl ether $(8 \times 30 \mathrm{~mL})$. The extract was washed with water $(2 \times 10 \mathrm{~mL})$, dried over sodium sulfate and evaporated in vacuo obtaining 6 in quantitatively yield as pale yellow solid. $[\alpha]_{\mathrm{D}}-38.0$ (c 1.0, $\mathrm{CH}_{2} \mathrm{Cl}_{2}$ ); Mp. $118-122^{\circ} \mathrm{C}$ (lit. ${ }^{1} \mathrm{Mp} .116-118^{\circ} \mathrm{C}$; lit. ${ }^{2}$ Mp. $152-154^{\circ} \mathrm{C}$ ); $\mathrm{IR}(\mathrm{KBr}$, $\mathrm{cm}^{-1}$ ): 2920, 1704, and 1684. ${ }^{1} \mathrm{H}$ NMR (400MHz, $\left.\mathrm{CDCl}_{3}\right): \delta$ (ppm, JHz): 0.97 (t, 3H-10, 7.33, 7.70); 1.25-1.40 (m, H-5, H-9); 1.51-1.62 (m, 2H-3, H-4); 1.80-1.89 (m, H-5, H-9); 2.01 (td, H4, 5.13, 5.50, 13.93); 2.34 (td, H-12, 1.44, 1.84); 2.37- 2.43 (m, 2H-6); 2.50-2.58 (m, H-2); 2.90 (t, H-8, 6.60); 2.94-2.98 (dd, H-12, 0.72, 17.24); 3.44 (dd, H-8, 1.83, 2.20, 6.42); 4.06 (dt, H-2, 1.44, 2.56, 12.83). ${ }^{13} \mathrm{C}$ NMR $\left(\mathrm{CDCl}_{3}\right): 6.94$ (C-10); 18.90 (C-3); 24.09 (C-4); 29.25 (C-9); 32.66 (C-12); 33.04 (C-5); 34.21 (C-4a); 35.47 (C-6); 40.57 (C-2); 42.56 (C-8); 65.94 (C-8a); 174.83 (C-11); 209.31 (C-7). HRMS (FAB+): Calcd for $\mathrm{C}_{13} \mathrm{H}_{19} \mathrm{NO}_{2}$ : 221.1416; found: 221.1395.

(-)-Tricyclic ketoamine (7). A solution of 6 (0.200 g, $0.90 \mathrm{mmol})$ in benzene (20 $\mathrm{mL})$, ethyilenglicol $(0.28 \mathrm{~mL}, 0.318 \mathrm{~g}, 4.6 \mathrm{mmol})$ and $p$-TsOH $(0.029 \mathrm{~g}, 0.15 \mathrm{mmol})$. The reaction mixture was refluxed for $3 \mathrm{~h}$ with the use of a Dean-Stark trap. The reaction was cooled, neutralized with saturated solution of $\mathrm{NaHCO}_{3}$ and extracted with diethyl ether (3x30 mL). The reaction mixture was concentrated in vacuo, and the resulting oil was immediately taken in THF $(15 \mathrm{~mL})$ and added dropwise to an ice-cooled solution of $\mathrm{LiAlH}_{4}(0.240 \mathrm{~g}, 6.3 \mathrm{mmol})$ in THF (10 $\mathrm{mL})$. The reaction mixture was stirred for $4 \mathrm{~h}$ and a solution of $\mathrm{NaOH}(15 \%, 2 \mathrm{~mL})$ was added. The mixture was filtered and the solution dried over sodium sulfate and evaporated in vacuo. The residue was dissolved in THF and treated with a solution of $\mathrm{HCl}(1 \mathrm{~N}, 1 \mathrm{~mL})$ and then neutralized with a solution of $\mathrm{NaOH}(1 \mathrm{~N}, 1 \mathrm{~mL})$. The solution was dried over sodium sulfate, the solvent evaporated in vacuo, and the residue was purified by column chromatography on $\mathrm{Al}_{2} \mathrm{O}_{3}$ (nhexane/ethyl acetate $90: 10$ ) to give 7 in $92 \%$ yield as pale yellow oil. [ $\alpha]_{\mathrm{D}}-16.0$ (c 1.0, $\mathrm{CH}_{2} \mathrm{Cl}_{2}$ ); IR $\left(\mathrm{KBr}, \mathrm{cm}^{-1}\right)$ : 2927, 1714. ${ }^{1} \mathrm{H}$ NMR (400MHz, $\left.\mathrm{CDCl}_{3}\right): \delta$ (ppm, JHz): 0.98 (t, 3H-10, 7.72); 1.15 (td, H-5, 4.04, 4.76); 1.36 (m, H-9); 1.52 (m, H-4); 1.62-1.76 (m, H-5); 1.72- 1.75 (m, H12); 1.82 (dd, H-8a, 2.20, 2.57, 12.46); 1.87-2.01 (m, 3H, 2H-2, H-9); 2.29 (td, H-4, 4.04, 4.40); 2.31-2.49 (m, 5H, 2H-3, 2H-6, H-12); 2.71 (dt, H-8, 1.84, 5.12); 3.04 (td, H-11, 2.60, 2.96, 8.96). 
${ }^{13} \mathrm{C}$ NMR ( $\mathrm{CDCl}_{3}$ ): 7.20 (C-10); 21.33 (C-3, C-12); 26.12 (C-4); 30.13 (C-9); 32.91 (C-5); 34.79 (C-4a); 36.88 (C-6); 48.22 (C-8); 52.98 (C-11); 53.29 (C-2); 73.62 (C-8a); 211.54 (C-7). HRMS (FAB+): Calcd for $\mathrm{C}_{13} \mathrm{H}_{21} \mathrm{NO}$ : 207.1623; found: 207.1610.

(+)-Dehydroaspidospermidine (8). To a solution of 7 (0.116 g, $0.56 \mathrm{mmol})$ in acetic acid (2 $\mathrm{mL})$ was added phenylhydrazine $(0.091 \mathrm{~g}, 0.84 \mathrm{mmol})$ in acetic acid $(2.5 \mathrm{~mL})$. The mixture reaction was heated at $95^{\circ} \mathrm{C}$ for $8 \mathrm{~h}$. After, the reaction was neutralized with a solution of $\mathrm{NaOH}$ $(15 \% 10 \mathrm{~mL})$ and extracted with $\mathrm{CH}_{2} \mathrm{Cl}_{2}(3 \times 20 \mathrm{~mL})$. The extract was dried over sodium sulfate, the solvent evaporated in vacuo, and the residue was purified by column chromatography on $\mathrm{Al}_{2} \mathrm{O}_{3}$. (n-hexane- $\mathrm{CH}_{2} \mathrm{Cl}_{2}, \mathrm{CH}_{2} \mathrm{Cl}_{2}$ ) to give 8 in $65 \%$ yield as yellow oil. $[\alpha]_{\mathrm{D}}+224.8$ (c 1.0, $\mathrm{CH}_{2} \mathrm{Cl}_{2}$ ); IR $\left(\mathrm{KBr}, \mathrm{cm}^{-1}\right): 2931,1696 .{ }^{1} \mathrm{H}$ NMR $\left(400 \mathrm{MHz}, \mathrm{CDCl}_{3}\right): \delta(\mathrm{ppm}, J \mathrm{~Hz}): 0.49$ (t, 3H-18, 7.33); 0.63 (m, H-19, 6.60, 6.97); 1.00 (td, H-17, 5.13); 1.45-1.68 (m, H-6, H-14, H-15, H-17, H19); 1.79-1.90 (m, H-14); 2.15 (qd, H-5, H-15, 4.40, 5.48, 11.88); 2.39 (s, H-21); 2.45 (td, H-16, 3.32, 3.68); 2.58 (m, H-3); 2.76 (td, H-16, 3.67, 12.46); 3.07-3.14 (m, H-5, H-16); 3.17 (t, H-3, 6.97, 8.07); 7.15 (t, H-11, 7.32, 7.36); 7.28 (d, H-9, 7.68); 7.31 (t, H-10, 7.36); 7.50 (d, H-12, 7.32). ${ }^{13} \mathrm{C}$ NMR $\left(\mathrm{CDCl}_{3}\right): 7.37$ (C-18); 22.11 (C-14); 23.80 (C-16); 27.26 (C-6); 29.80 (C-19); 33.28 (C-17); 35.22 (C-15); 36.56 (C-20); 52.10 (C-5); 54.65 (C-3) 61.35 (C-7); 79.11 (C-21); 120.18 (C-12); 121.07 (C-10); 125.16 (C-11); 127.53 (C-9); 147.21 (C-8); 154.59 (C-13); 192.44 (C-2). HRMS (FAB+): Calcd for $\mathrm{C}_{19} \mathrm{H}_{24} \mathrm{~N}_{2}$ : 280.1939; found: 280.1928 .

(+)-Aspidospermidine (9). To a solution of $8(0.60 \mathrm{~g}, 0.20 \mathrm{mmol})$ in methanol $(10 \mathrm{~mL})$ was added $\mathrm{NaBH}_{4}(0.38 \mathrm{~g}, 1.00 \mathrm{mmol})$ at $0^{\circ} \mathrm{C}$. After stirring for $1 \mathrm{~h}$ at $0^{\circ} \mathrm{C}$, followed by $1 \mathrm{~h}$ at room temperature, the reaction mixture was diluted with ether, washed to ice twice with water, dried over sodium sulfate, and concentrated under reduced pressure. The residue was purified by flash column chromatography on $\mathrm{Al}_{2} \mathrm{O}_{3}$ ( $n$-hexane/dichloromethane $\left.1: 1\right)$ to give $\mathbf{9}$ in $95 \%$ yield as a pale yellow solid. $[\alpha]_{\mathrm{D}}+18.0$ (c 1.0, EtOH), Mp $118-120^{\circ} \mathrm{C}$; (lit. ${ }^{6}[\alpha]_{\mathrm{D}}+20.6$ (c 0.64 , EtOH) and Mp 118-119 ${ }^{\circ}$ ); ( lit. $^{7}[\alpha]_{\mathrm{D}}+17.0$ (c 1.0, EtOH) and Mp 120-121 ${ }^{\circ} \mathrm{C}$ ); ( lit. ${ }^{8}[\alpha]_{\mathrm{D}}+20.8$ (c 2.4, EtOH) and Mp 117-118 ${ }^{\circ}$ ); IR (KBr, $\left.\mathrm{cm}^{-1}\right): 3309,2929,1466 .{ }^{1} \mathrm{H}$ NMR $\left(400 \mathrm{MHz}, \mathrm{CDCl}_{3}\right): \delta$ (ppm, JHz): 0.63 (t, 3H-18, 7.33); 0.86 (sext. H-19, 6.97, 7.33); 1.06 (dt, H-14, H-15); 1.10 (td, H-17, 4.40, 13.56); 1.39 (m, H-16); 1.43-1.54 (m, H-6, H-19); 1.60-1.75 (m, H-16, H-17); 1.93 (td, H-3, H-14, H-15); 2.20 (s, H-21); 2.24-2.32 (m, H-5, H-6); 3.05 (d, H-3, 10.63); 3.12 (t, H-5, 8.07, 9.17); 3.50 (dd, H-2, 5.87, 6.23, 10.81); 6.63 (d, H-12, 7.70); 6.72 (t, H-10, 7.33); 7.01 (t, $\mathrm{H}-11,7.70) ; 7.07$ (d, H-9, 7.33); 7.25 (s, N-H). ${ }^{13} \mathrm{C}$ NMR $\left(\mathrm{CDCl}_{3}\right): 6.90$ (C-18); 21.85 (C-15); 23.07 (C-14); 28.18 (C-16); 30.06 (C-19); 34.55 (C-17); 35.72 (C-20); 38.91 (C-6); 53.11 (C-5); 53.45 (C-7); 53.95 (C-3); 65.75 (C-2); 71.36 (C-21); 110.42 (C-12); 119.06 (C-10); 122.91 (C9); 127.15 (C-11); 135.80 (C-8); 149.49 (C-13). HRMS (FAB+): Calcd for $\mathrm{C}_{19} \mathrm{H}_{26} \mathrm{~N}_{2}$ : 282.2096; found: 282.2088 .

\section{Acknowledgments}


D. G. and A. G. we are grateful for financial support from CONACyT-México (Project 28906N).

E. V. thanks to CONACyT for a doctoral scholarship \# 121966.

\section{References}

1. Stork, G.; Dolfini, J. E. J. Am. Chem. Soc. 1963, 85, 2872.

2. Meyers, A. I.; Berney D. J. Org. Chem. 1989, 54, 4673. and references cited therein.

3. Kozmin, S. A.; Iwama, T.; Huang, Y.; Rawal, V. H. J. Am. Chem. Soc. 2002, 124, 4628.

4. Vázquez, E.; Galindo, A.; Gnecco, D.; Bernès, S. Tetrahedron: Asymmetry 2001, 12, 2099.

5. Jankowski, K.; Labrecque, D.; Jones, P.; Paré, J. R. Spectroscopy 1991, 9, 39.

6. Iyengar, R.; Schildknegt.; Aubé J. Organic Letters. 2000, 2, 1625.

7. Desmäele, D.; d'Angelo, J. J. Org. Chem. 1994, 59, 2292 and references cited therein.

8. Schultz, A. G.; Pettus, L. J. Org. Chem. 1997, 62, 6855 and references cited therein.

9. Sheldrick, G. M. SHELX97 Users Manual, University of Göttingen, Germany, 1997. 